\title{
Molecular study of HBZ and gp21 Human T cell lymphotropic virus type 1 proteins isolated from different clinical profile infected individuals
}

\author{
Aline CA Mota-Miranda ${ }^{1,2,3}$, Fernanda K Barreto ${ }^{1}$, Everton Baptista ${ }^{1}$, Joana P Monteiro-Cunha ${ }^{1,2,3}$, \\ Lourdes Farre-Valve ${ }^{1}$, Bernardo Galvao-Castro ${ }^{1,2}$, Luiz CJ Alcantara ${ }^{1 *}$ \\ From 16th International Conference on Human Retroviruses: HTLV and Related Viruses \\ Montreal, Canada. 26-30 June 2013
}

The HTLV-1 gp21 glycoprotein is involved in envelope trafficking and membrane targeting while bZIP protein is indispensable for cell growth and proliferation. This study aimed to assess the molecular diversity of gp21 and HBZ proteins, in TSP/HAM and healthy carriers. DNA samples from HTLV-1 infected individuals were submitted to PCR, sequencing, and the molecular analyses were performed using bioinformatics tools. From eight gp 21 analyzed sequences one amino acid change $(\mathrm{Y} 477 \mathrm{H})$ was associated to the switch of helix to coil structure at secondary structure prediction. From ten HBZ analyzed sequences, two amino acid changes were identified (S9P and T95I) at the activation domain. One mutation (R112C) located at nuclear localization signal was present in $66.7 \%$ and $25 \%$ of $\mathrm{HC}$ and TSP/HAM groups, respectively. This is the first report of mutations in HBZ region. These polymorphisms might be important for viral fitness.

\section{Authors' details}

${ }^{1}$ CPqGM/FIOCRUZ, Salvador, Bahia, Brazil. ${ }^{2}$ EBMSP, Salvador, Bahia, Brazil.

${ }^{3}$ UFBA, Salvador, Bahia, Brasil.

Published: 7 January 2014

doi:10.1186/1742-4690-11-S1-P84

Cite this article as: Mota-Miranda et al:: Molecular study of HBZ and gp21 Human T cell lymphotropic virus type 1 proteins isolated from different clinical profile infected individuals. Retrovirology 2014 11(Suppl 1):P84.
Submit your next manuscript to BioMed Central and take full advantage of:

- Convenient online submission

- Thorough peer review

- No space constraints or color figure charges

- Immediate publication on acceptance

- Inclusion in PubMed, CAS, Scopus and Google Scholar

- Research which is freely available for redistribution

Submit your manuscript at

www.biomedcentral.com/submit
() Biomed Central

* Correspondence: lalcan@bahia.fiocruz.br

'CPqGM/FIOCRUZ, Salvador, Bahia, Brazil

Full list of author information is available at the end of the article

(c) 2014 Mota-Miranda et al; licensee BioMed Central Ltd. This is an Open Access article distributed under the terms of the Creative Commons Attribution License (http://creativecommons.org/licenses/by/2.0), which permits unrestricted use, distribution, and reproduction in any medium, provided the original work is properly cited. The Creative Commons Public Domain Dedication waiver (http://creativecommons.org/publicdomain/zero/1.0/) applies to the data made available in this article, unless otherwise stated. 